UDK $541.18 .046+628.16$

\title{
COMPARISON OF POLYALUMINUM SILICATE CHLORIDE AND ELECTROCOAGULATION PROCESS, IN NATURAL ORGANIC MATTER REMOVAL FROM SURFACE WATER IN GHOCHAN, IRAN
}

\author{
A.H. Mahvi ${ }^{1,2}$, M. Malakootian ${ }^{3}$, M.R. Heidari ${ }^{3}$ \\ ${ }^{1}$ School of Public Health and Center for Environmental research, \\ Tehran University of Medical Sciences, Tehran, Iran; \\ ${ }^{2}$ National Institute of Health Research, Ministry of Health, Tehran, \\ Iran; \\ ${ }^{3}$ Department of Environmental Health, School of Public Health, \\ Kerman University of Medical Sciences, Kerman, Iran
}

Recieved 10.09.2010

\begin{abstract}
Removal of Natural Organic Matter (NOM)is one of the most important objectives of water treatment plants butreducing these pollutants either present in water as dissolved or suspended form is not as efficient as is required in conventional treatment plants. The purpose of this study was comparison performance of composite polyaluminum silicate chloride (PASiC) and electrocoagulation (EC) process by aluminum electrodes in NOM removal from raw surface water. In this study, the effects of turbidity, total organic compounds carbons (TOC), adsorption at a wavelength of $254 \mathrm{~nm}$ (UV254 $\mathrm{nm})$, chemical oxygen demand (COD), alkalinity, residual aluminum in finished water by application of EC process and PASiC were investigated. The results demonstrate that PASiC coagulant at optimum concentration of $1-5(\mathrm{ml} / \mathrm{L})$ was capable of removing TOC, COD, UV254, and turbidity from raw water by 93.77, 93.5, 63 and 95\%, respectively. In contrast, EC process, removed TOC, COD, UV254 and turbidity from raw water by 89, 99.75, 37 and 50\%, respectively. The pilot-scale results demonstrated the significant advantage of PASiC compared to EC process in removal of NOM and turbidity form raw water. Residual aluminum in finished water was below the recommended World Health Organization guidelines $(0.2 \mathrm{mg} / \mathrm{L})$ for both processes. Finally it can be concluded that PASiC and EC process are reliable, efficient and costeffective methods for removal of NOM from surface water.
\end{abstract} chloride.

Keywords: electrocoagulation, natural organic matter, polyaluminum silicate (C) A.H. MAHVI, M. MALAKOOTIAN, M.R. HEIDARI, 2011 


\section{Introduction}

Presence of high concentration of NOM is one of the major pollutants in surface water sources. The presence of NOM can cause odor and taste in the finished treated water and could lead to additional treatment costs [1]. NOM contains roughly $40-60 \%$ carbon and $1-5 \%$ nitrogen by weight, respectively [2]. NOM concentration in water treatment plants is 2.47 and $1.63 \mathrm{mg} / \mathrm{L}$ respectively. The mean of total percent of hydrophobic and hydrophilic fraction is about 41 and 59\% [3]. During water treatment process, nitrogenous moieties of NOM can react with disinfectants to form carcinogenic, and adverse birth outcomes, trihalomethanes and haloacetic acids $[2,4,5]$. WHO has given a recommendation guideline of below $0.3 \mathrm{mg} / \mathrm{L}$ [1]. Current options for dissolved organic carbon (DOC) removal includes membrane filtration $(80-99 \%)$, activated carbon filtration $(53-95 \%)$, ion exchange $(60-80 \%)$, ozonation/biodegradation $(25-75 \%)$ and coagulation with cationic additives $(10-60 \%)[6,7]$. NOM can be removed from water by conventional surface water treatment processes mainly such of coagulation, sedimentation, and gravity ltration [7]. During coagulation process NOM is removed through charge neutralization, entrapment, and sorption onto oc surfaces. In recent decade, aluminum or iron-based compounds such as ferric sulfate (FS), alum, aluminum chloride, polyaluminum chloride (PAC) are widely used for removal of DOC [8]. In contrast, a research demonstrated that $\mathrm{Al}$ and $\mathrm{Fe}$ salts were not efficiently desirable in removal of natural organic matter [9]. Therefore, there is a need to a new coagulant in order to improve the performance in NOM removal from water.

Development of PASiC under certain conditions was in mind. In this regard, PAC and activated silica, a polysilicate (PSi), could be combined eith each other in order to get a compound based on (PAC) as a new coagulant [10]. PASiC is a new type of inorganic polymer coagulant, having a larger particle size and better turbidity and color removal efficiency than PAC [11]. Gao and Yue et al. in their recent studies applied PASiC for removal of algae, turbidity, oil, COD and TP under the laboratory conditions [12].

EC is a an emerging and efficient method in water treatment where the flocculating agent is generated by ion exchange process using electrochemical of a sacrificial anode $[13,14]$. In electrocoagulation process, there is no addition of chemicals to the water. Therefore, in this process a small volume of sludge is produced, comparing with conventional coagulation process in water treatment and such sludge can be easily removed by decantation $[12,15]$. Currently, in the EC process aluminum or iron plates are used as electrodes [16]. 
In recent years, it has been increasing interest in the use of electrochemistry for water and wastewater treatment. EC process has been widely researched in the field of water and wastewater treatment to remove heavy metals, chemical compounds, microorganism, hardness, turbidity, and other environmental contaminants [17 - 18].

In a research in Taiwan, EC process was investigated for removal of TOC from aqueous solution containing polyvinyl alcohol (PVA). The PVA and TOC removal efficiencies were significantly influenced by the current density and temperature [19]. In another survey the removal of NOM from drinking water which was treated by coagulation - microfiltration using metal membranes resulted in more than $95 \%$ color removal, $85 \%$ UV removal, $65-75 \%$ TOC removal and turbidity reached less than 0.2 NTU and non-detectable suspended solids in the finished water [20]. Zazouli and et al. in a research on application of nanofiltration membrane showed that the average rejection efficiency of humic acid and salt ranged between $91.2-$ $95.25 \%$ and $63.6-80 \%$ respectively [21].

This paper investigates comparison of $\mathrm{PaSiC}$ and the EC process, in removal of NOM from raw surface water in Ghouchan water treatment plant.

\section{Experimental}

Preparation of coagulants. The preparation of PASiC coagulant is briefly described below. At first, $10,75 \mathrm{ml}$ of concentrated $3 \mathrm{M} \mathrm{SiO}_{2}$ solution was introduced slowly into $10 \mathrm{ml}$ of $2 \mathrm{M}$ hydrochloric acid solution while stirring to obtain a PSi solution ( $\mathrm{pH}$ value of $2.0-2.2$ ). Then, fresh PSi solution was mixed with $2.5 \mathrm{M} \mathrm{AlCl}_{3}$ solution at $\mathrm{Al}$ to $\mathrm{Si}$ ratio of at least 10 . Then, $1.5 \mathrm{M}$ $\mathrm{Na}_{2} \mathrm{CO}_{3}$ solutions were added to the solution slowly under stirring condition to obtain an $\mathrm{OH}$ to $\mathrm{Al}$ ratio equal to 2 . The above solution had the following properties: $\mathrm{Al}_{2} \mathrm{O}_{3}+\mathrm{SiO}_{2}$ content $=10.0 \%, \mathrm{Al} / \mathrm{Si}=10, \gamma=2, \mathrm{pH}=1.5-3.5$, and density $=1-1.5 \mathrm{~g} / \mathrm{Cm}^{3}[22]$.

EC unit. A $200 \mathrm{ml}$ beaker was used as EC cell. Eight sheets of rectangular laminate aluminum was used as electrode, each $(8 \times 10) \mathrm{cm}$ and the distance between the plates was fixed about $1 \mathrm{~cm}$. Electrodes were connected to direct current power supply with $10-30 \mathrm{~V}$ as maximal tension and $15 \mathrm{~A}$ (Fig. 1).

Before the EC test, and in order to avoid any interference, the electrodes were rinsed with distilled water then cleaned with $\mathrm{HCl}$ solution (1:1) and finally they were rinsed again with distilled water. 


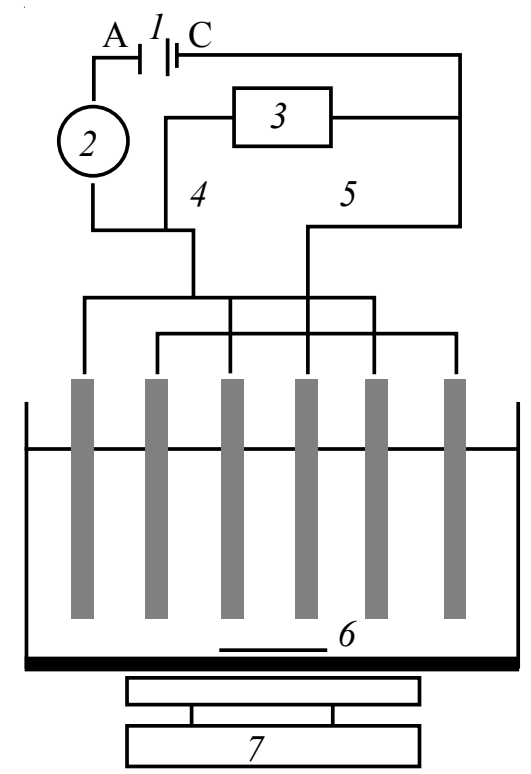

1 - DC power supply

2 - Digital amperemeter

3 - Digital voltmeter

4 - Anode rod

5 - Cathode rod

6 - Magnetic bar

7 - Magnetic stirring controller

Fig. 1. Schematic diagram of the electrocoagulation pilot plant.

\section{Analytical methods}

Coagulation procedure was carried out using a six paddle gang stirrer jar test with six one-liter beakers. An initial rapid mixing was set at $120 \mathrm{rpm}$ for two min followed by a slow mixing at $45 \mathrm{rpm}$ for $10 \mathrm{~min}$ then settling for $15 \mathrm{~min}$. After sedimentation, supernatant samples were taken from a point $2 \mathrm{~cm}$ below the surface for analysis.

Turbidity was measured by a Eutech Turbidimeter (Model 5310), and pH was measured by Eutech $\mathrm{pH}$ meter. TOC of the samples were measured using DR/5000 Spectrophotometer, UV254 absorbance and residual aluminum was measured by UV/Vis Spectrophotometer ("Shimadzu", Japan) with $1.0 \mathrm{~cm}$ quartz cells COD was determined by the potassium dichromate method according to the Standard Method for Examination of Water and Wastewater [23]. In all the experiments, in order to neglect the effect of $\mathrm{pH}$ on the NOM removal efficiency, the $\mathrm{pH}$ of the water was adjusted with $0.1 \mathrm{M} \mathrm{HCl}$ solution or $0.1 \mathrm{M} \mathrm{NaOH}$ solution.

Removal efficiencies (R, \%) were calculated according to equation below:

$$
\mathrm{R}=[(\mathrm{CO}-\mathrm{CE}) / \mathrm{CO}] \cdot 100 .
$$




\section{Results and discussion}

Application of PASiC coagulant. Results of PASiC experiments for TOC, COD, and UV254 removal are shown in Fig. 2 - 4.The results demonstrated that, required coagulant dosage for TOC, COD, and UV254 removal increases with NOM increment. As illustrated in Fig. 2 - 4, applying an optimum dosage of $1 \mathrm{ml} / \mathrm{L}$ at $\mathrm{pH} 7$ resulted in 93.77, 93.5, and 63\% removals of TOC, COD, and UV254, respectively. As the initial coagulant concentration increased, the removal efficiency decreased, and the range of removal efficiency was 91 95\% . The effect of PASiC doses on turbidity removal is shown in Fig. 5, at initial $\mathrm{pH}$ of water. As shown, turbidity removal generally increases with increasing coagulant dose. According to this Fig. 5, the maximum turbidity removal rates obtained at initial $\mathrm{pH}$ of water is $95 \%$. The results obtained from the experiment showed that increases in raw water turbidity up to $100 \mathrm{NTU}$ led to an increase in turbidity removal efficiency. Therefore, the treated water residual turbidity was always below 0.2 NTU for all samples tested. Fig. 6 shows the volume of settled sludge after coagulation in its optimum $\mathrm{pH}$. As in Fig. 7, residual aluminum in treated water increases with increasing coagulant dose. It is clear that PASiC not only have any positive effect on NOM removal but also it increases turbidity and the volume of settled sludge. The appropriate setting time was obtained about $15 \mathrm{~min}$. The appropriate amount of sludge production can cause reduction in sludge disposal problem and extra costs.

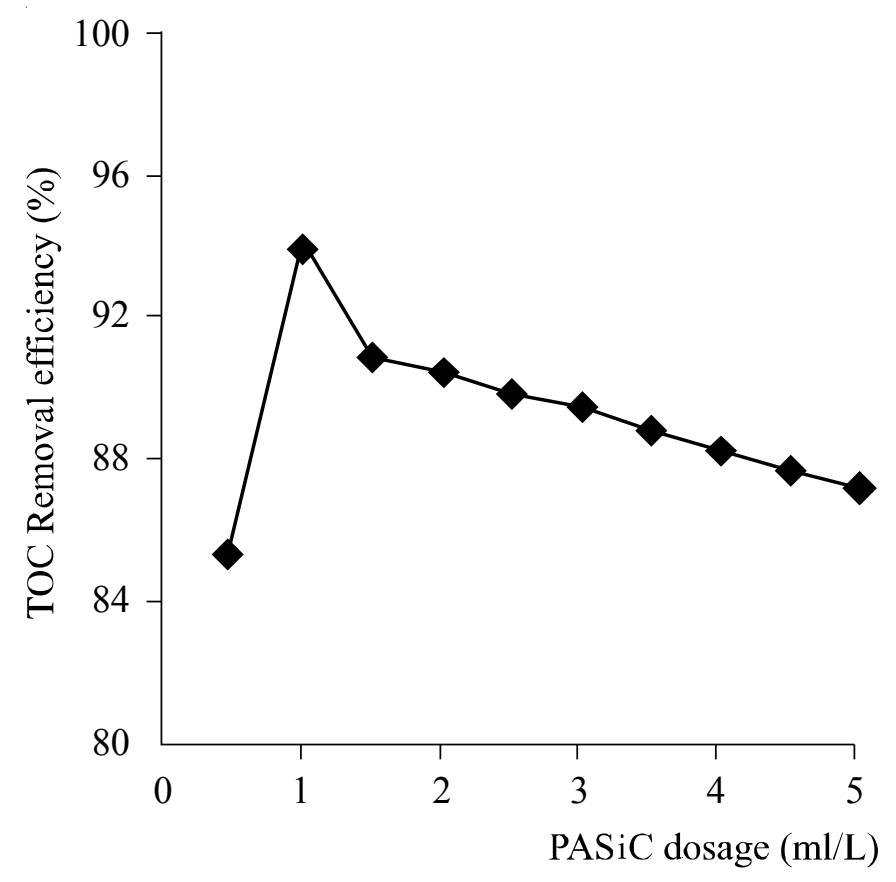

Fig. 2. TOC removal percentage by PASiC in natural $\mathrm{pH}$. 


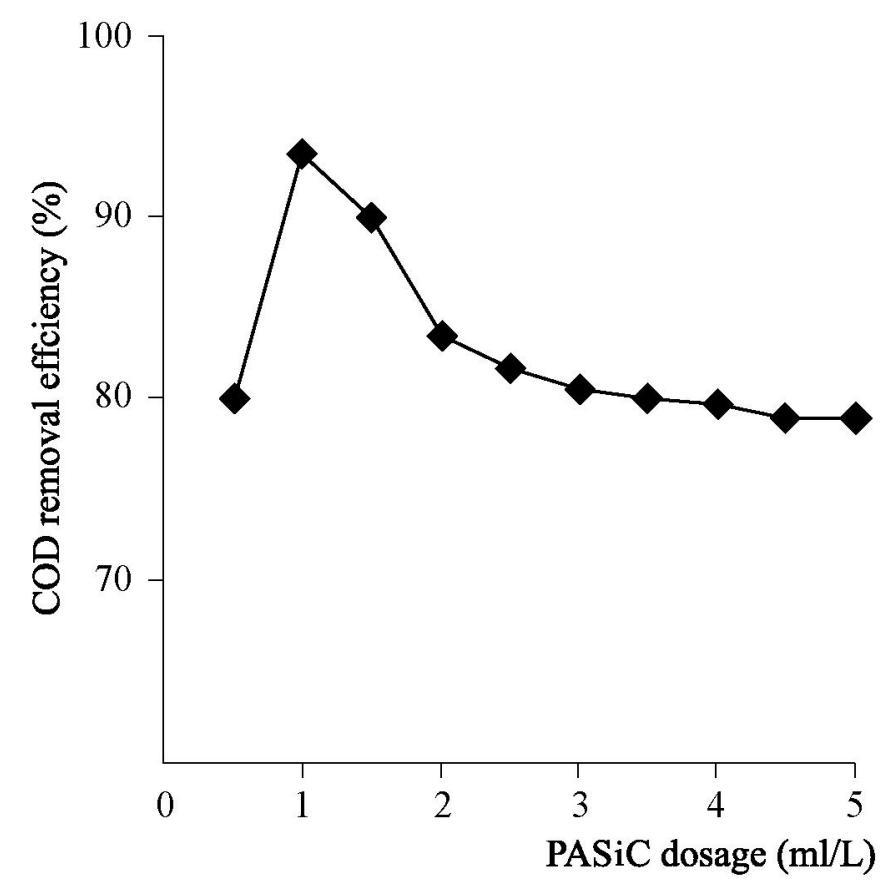

Fig. 3. COD removal percentage by $P A S i C$ in natural $p H$.

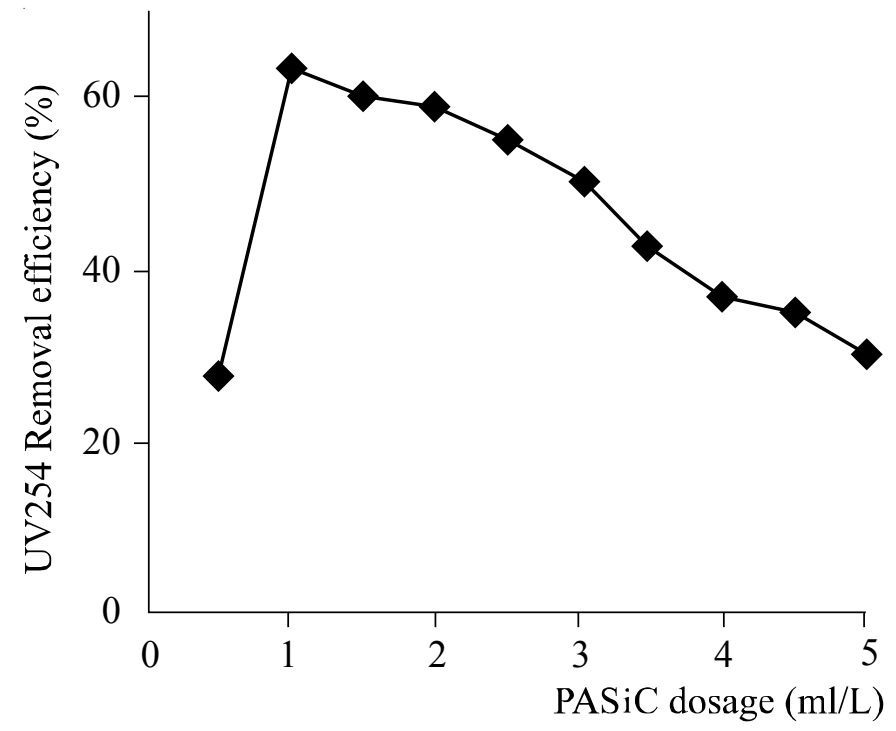

Fig. 4. Removal percentage UV254 by PASiC in natural $p H$. 


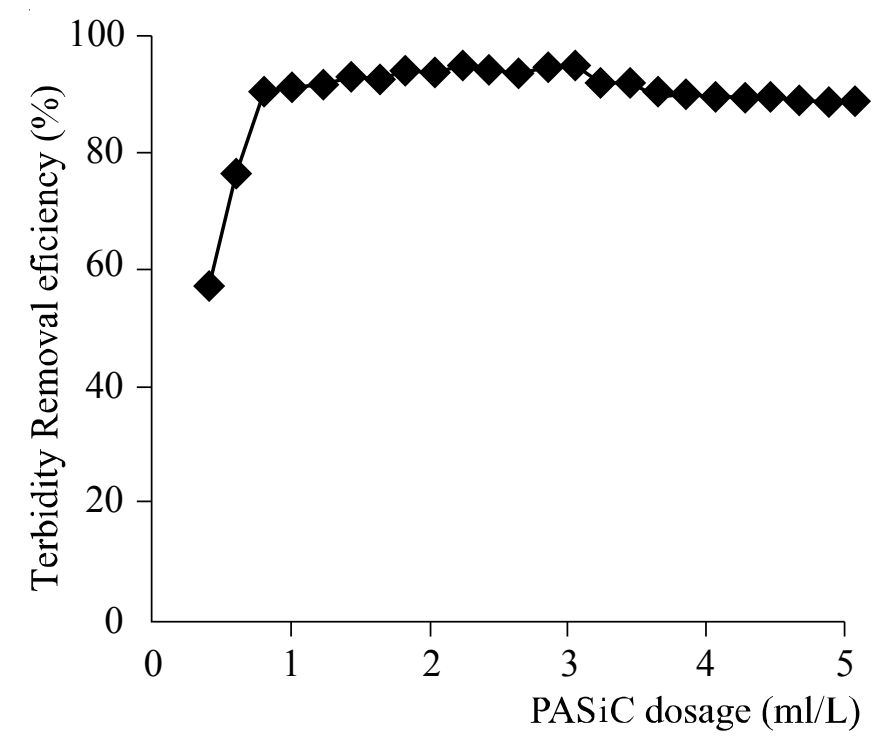

Fig. 5. Turbidity removal percentage by $P A S i C$ in natural $p H$.

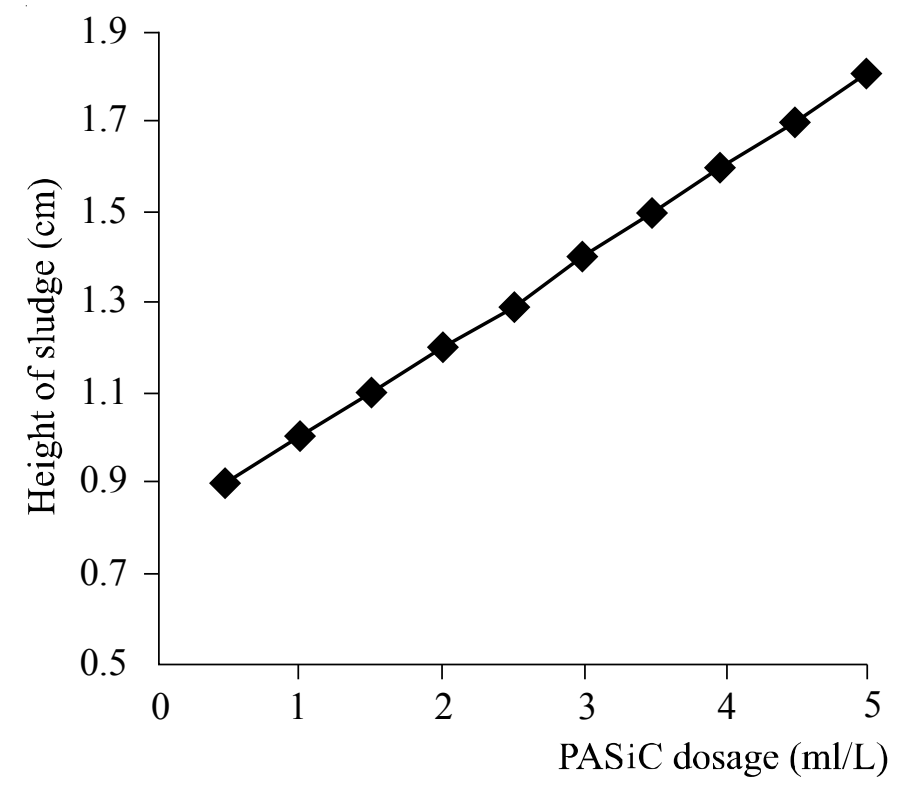

Fig. 6. Height of sludge by PASiC in natural $\mathrm{pH}$. 


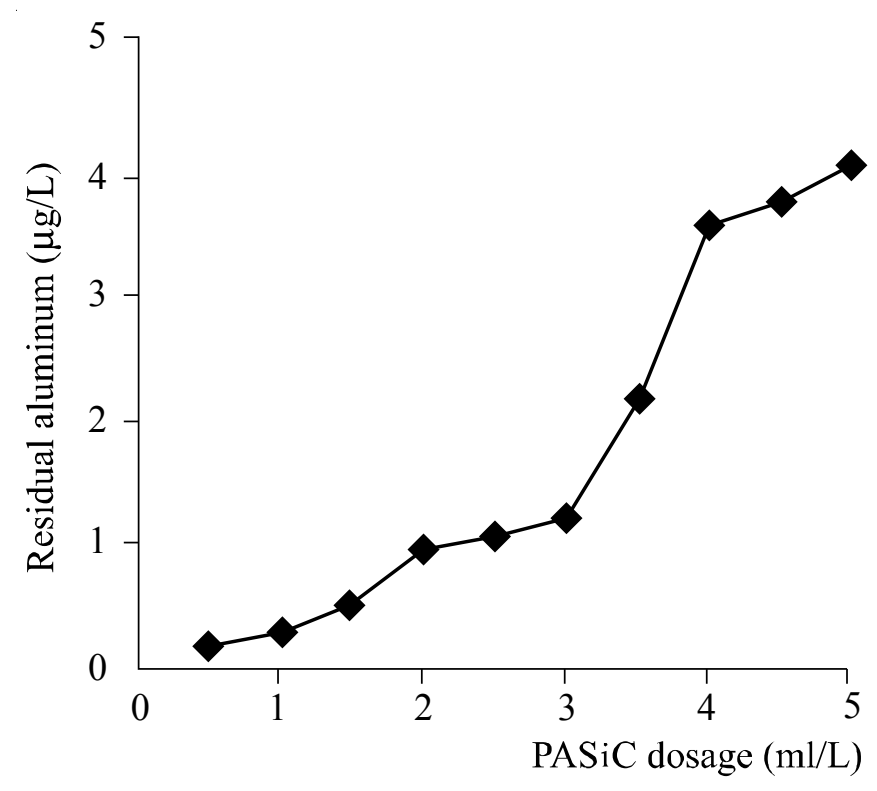

Fig. 7. Residual aluminum rate by PASiC in natural $\mathrm{pH}$

Application of EC process. Fig. 8 - 10 represent the percent of TOC, COD and UV254 removal in different $\mathrm{pH}$, electrical potential (voltage) and time intervals. As it is seen, at time $60 \mathrm{~min}, \mathrm{pH} 6.5$ and electrical potential of $30 \mathrm{~V}$ the maximum removal efficiency was achieved which was $89 \%, 99.75 \%$, and $38 \%$ removal in TOC, COD, and UV254, respectively. During experiment, the most effective removal parameter was electrical potential in $30 \mathrm{~V}$. These results illustrated that with increase in time up to $30 \mathrm{~min}$, the amount of removal rate increases considerably, but whit the increase of electrical potential, in the range of $30-60 \mathrm{~V}$ and time in the range of $30-60$ min no impressive enhancement will occur in treatment efficiency. The results show that the most turbidity removal rate of 50\% was achieved in $30 \mathrm{~min}, \mathrm{pH} 6,5$ and electrical potential in $30 \mathrm{~V}$ (Fig. 11). Maximum removal rate was achieved in the initial period of $30 \mathrm{~min}$ time and by time passes in the range of $30-60 \mathrm{~min}$, turbidity removal rate decreases. Results showed that residual aluminum concentrations in all experiments are below $0,2 \mathrm{mg} / \mathrm{L}$ the recommended guideline for aluminum goal (Fig. 12). 


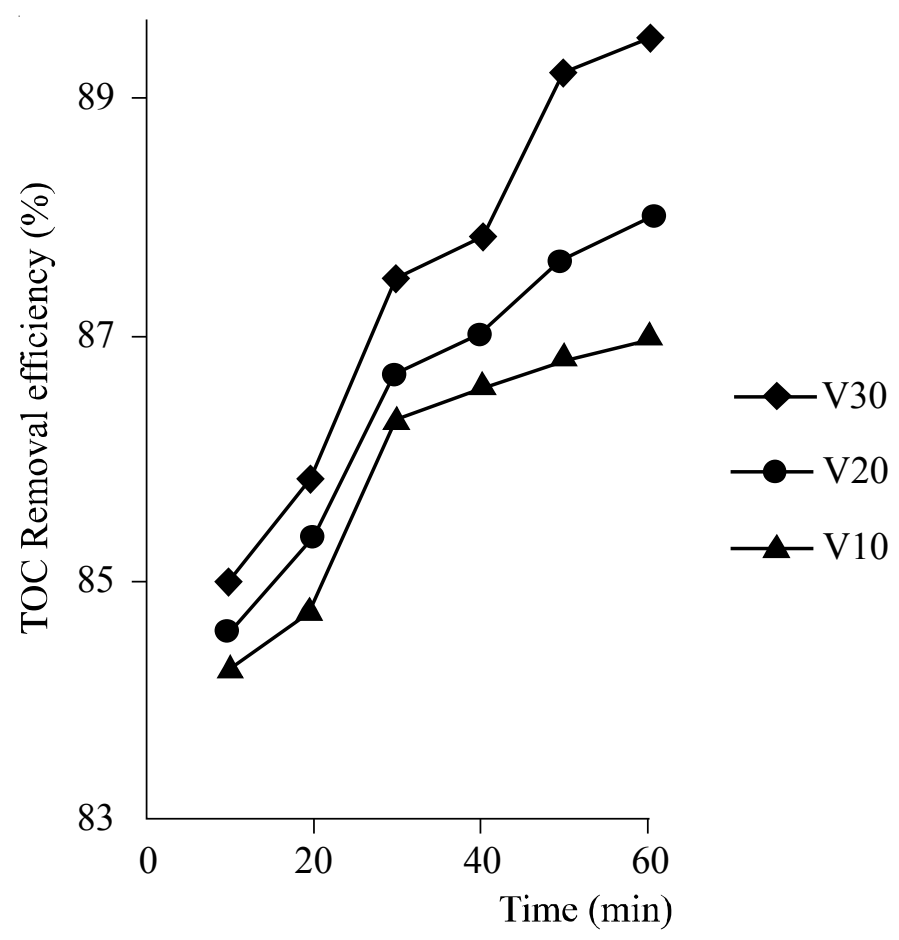

Fig. 8. TOC removal by EC in $p H 6.5$ different $V$.

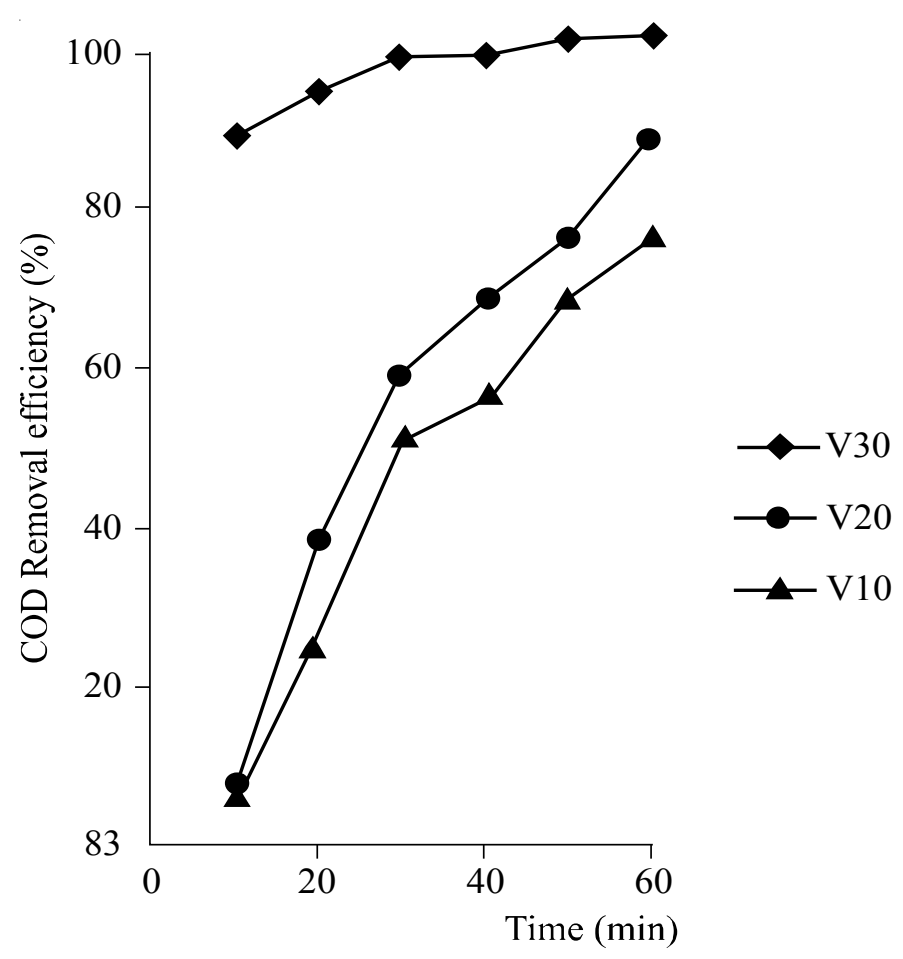

Fig. 9. COD removal by EC in $\mathrm{pH} 6.5$ different $V$. 


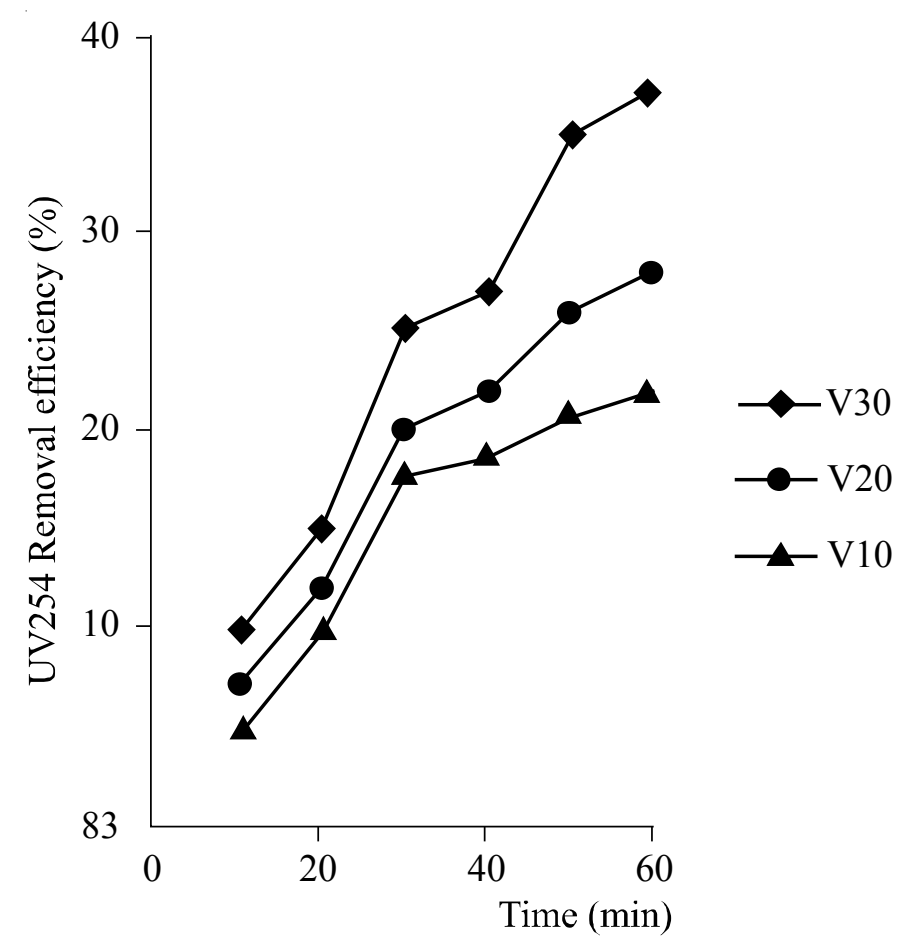

Fig. 10. UV254 removal by EC in pH 6.5 different $V$

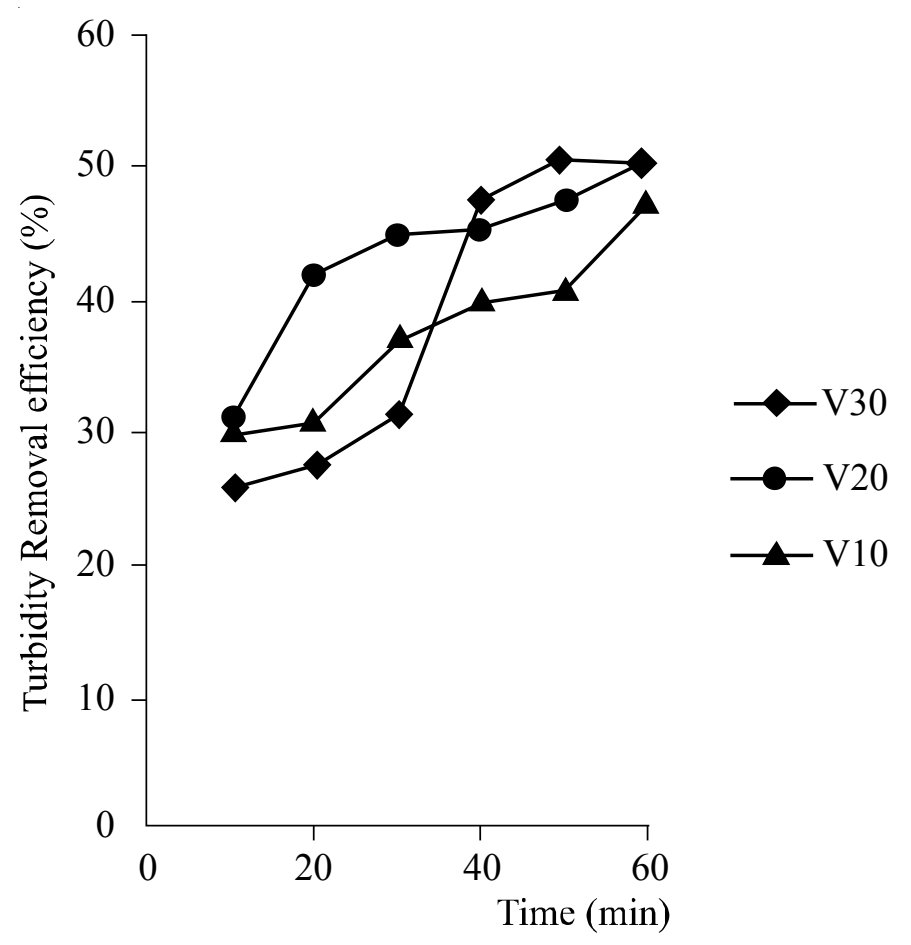

Fig. 11. Turbidity removal by EC in $\mathrm{pH} 6.5$ different $V$ 


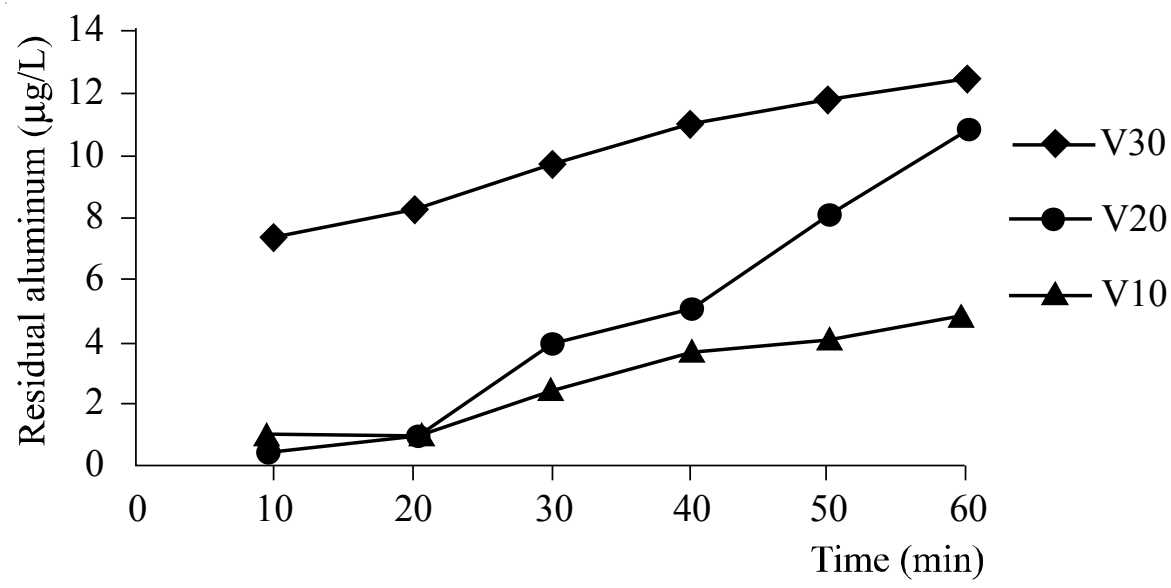

Fig. 12. Residual aluminum of by EC in $\mathrm{pH} 6.5$ different $V$

\section{Conclusions}

This study has shown that lower doses of PASiC coagulant have high efficiency in NOM and turbidity removal, these results are in accordance whit a research on PASiC [10]. It can be concluded that the PASiC coagulant has the potential to be utilized as cost-effective alternative coagulant in surface water treatment plants. The experiments show that EC process in operating time of $10 \mathrm{~min}, \mathrm{pH} 6.5$ and electrical potential in 30 volt is capable in the removal of NOM and turbidity. The NOM removal rate was seen to increase with increasing the current power and reaction time.

These results are in agreement with the findings in the study on COD and turbidity removal efficiency from water through electrocoagulation process [15]. Also the results are in matched with results of another research on iron chemical coagulation and EC pretreatment [9], Zhu and et al. suggest that EC might also be superior to conventional coagulation for NOM removal during membrane pretreatment [12].

The turbidity removal performance of the coagulants varied according to the following order: $\mathrm{PASiC}>\mathrm{AlCl}_{3}>\mathrm{PAC}>\mathrm{Al}_{2}\left(\mathrm{SO}_{4}\right)_{3}$ and it could reach about 95; 94; $91,5 \%$ and $90,5 \%$ for $\mathrm{PASiC}, \mathrm{AlCl}_{3}, \mathrm{PAC}, \mathrm{Al}_{2}\left(\mathrm{SO}_{4}\right)_{3}$, respectively [8].Residual aluminum of PASiC coagulation reduced to less than $4,1 \mathrm{mg} / \mathrm{L}$ and for electrocoagulation was below $15 \mathrm{mg} / \mathrm{L}$ [4]. Scientific issues on the association between $\mathrm{Al}$ and Alzheimer's disease are pending resolution [8].The residual aluminum ratio of the three coagulants varied according to the following order: $\mathrm{Al}_{2}\left(\mathrm{SO}_{4}\right)_{3}>\mathrm{AlCl}_{3}>\mathrm{PAC}$ [8]. However, the residual aluminum in the treated finished water was much below the acceptable potable water standard of $0,2 \mathrm{mg} / \mathrm{L}$. 
The comparison of PASiC coagulant and electrocoagulation used for surface water treatment, demonstrated the practical advantage of PASiC coagulant for water treatment in terms of effectiveness. Finally, concluded that both PASiC coagulant and electrocoagulation method is a reliable, safe, efficient and cost-effective method in removal of NOM from surface waters.

\section{Acknowledgements}

The authors would like to thank Environmental Health Research Committee of Kerman University of Medical Sciences and Khorasan Razavi Water and Wastewater company for financial support of this research. They also appreciate Ms. Navidi and Ms. Eng Ghouchani for their assistance in the water treatment plant.

Резюме. Удаление природных органических веществ (ПОВ) является одной из наиболее важных задач при очистке поверхностных вод. Однако удаление ПОВ, находящихся в растворенной форме или в виде суспензий, не настолько эффективно, как это требуется при работе водоочистных сооружений. Изучено влияние мутности, общего органического углерода (ООУ), адсорбции ПОВ при длине волны 254 нм (УФ254 нм), ХПК, щелочности в процессе электрокоагуляции и при использовании композитного четыреххлористого кремния полиалюминия (КЧКП). Показано, что КЧКП при оптимальной концентрации $1 \cdot 10^{-3}-$ $5 \cdot 10^{-3}$ дм $^{3} /$ дм $^{3}$ позволяет снизить ООУ, ХПК, УФ254 и мутность соответственно на 93,8; 93,5; 63 и 95\%. Экспериментальные результаты свидетельствуют о значительном преимуществе КЧКП по сравнению с процессом электрокоагуляции при удалении ПОВ и мутности из неочищенной воды. Остаточный алюминий в очищенной воде находился ниже норм, рекомендуемых Всемирной организацией здравоохранения $(0,2$ мг/дм³), для обоих процессов. Таким образом, можно сделать вывод, что КЧКП и электрокоагуляция являются надежными и эффективными методами для удаления ПОВ из поверхностной воды.

Резюме. Видалення природних органічних речовин (ПОР) є одним 3 найбільш важливих завдань при очищенні поверхневих вод. Проте видалення ПОР, що знаходяться в розчиненій формі або у вигляді суспензій, не настільки ефективно, як це потрібно при роботі водоочисних споруд. Вивчений вплив каламутності, загального органічного вуглецю (3ОУ), адсорбції ПОР при довжині хвилі 254 нм (УФ254 нм), ХПК, лужності в процесі електрокоагуляції і при використанні композитного чотирьоххлорістого кремнію поліалюмінію (КЧКП). Показано, що КЧКП при оптимальній концентрації $1 \cdot 10^{-3}-5 \cdot 10^{-3}$ дм $^{3} /$ дм $^{3}$ дозволяє понизити 3ОУ, ХПК, УФ254 і каламутність відповідно на 93,8; 93,5; 63 і 95\%. Експери- 
ментальні результати свідчать про значну перевагу КЧКП в порівнянні 3 процесом електрокоагуляції при видаленні ПОР і каламутності з неочищеної води. Залишковий алюміній в очищеній воді знаходився нижчим за норми, що рекомендуються Всесвітньою організацією охорони здороâ'ÿ (0,2 ì ã/äì $\left.{ }^{3}\right)$, для обох процесів. Таким чином, можна зробити висновок, що КЧКП і електрокоагуляція є надійними і ефективними методами для видалення ПОР з поверхневої води.

1. Qin J., Htun O., Kiran M., Kekre A., Knops F., Miller P. // Separ. and Purif. Technol. - 2006. - 49. - P. 295 - 298.

2. Leea W., Westerhoff P. //Water Resh. - 2006. - 40. - P. 3767 - 3774.

3. Zazouli M.A., Nasseri S., Mahvi A.H., Mesdaghinia A.R., Younecian M., Gholami M. // J. Appl. Sci. - 2007. - 7, N18. - P. 2651 - 2655.

4. Selcuka H., Rizzob L., Nikolaouc A.N., Mericb S., Belgiornob V., Bekboletd M. // Desalination. - 2007. - 210. - P. 31 - 43.

5. Duan J., Wangb J., Grahanf N., Wilsonb F., Wark I. //Ibid. -2002. - 150. - P. 1 - 14.

6. Sharp E. L., Parsons S.A., Jefferson B.// Sci. Total Environ. - 2006. - 363. P. $183-194$.

7. Matilainen A., Vieno N., Tuhkanen T.//Environ. Int. - 2006. - 32. - P. 324-331.

8. Yang Z.L., Gao B.Y., Yue Q.Y., Wang Y.//Hazard. Materials. -2010. - 178. P. $596-603$.

9. Bagga A., Chellam S., Clifford D. A. // Membrane Sci. - 2008. - 309. -P. 82 - 93.

10. Gao B.Y., Yue Q.Y., Wang B.J., Chu Y.B. // Colloids and surfaces, A. - 2003. 229. - P.121-127.

11. Gao B.Y., Hahn H.H., Hoffmann E.//Water Res. - 2002. - 36. - P.573 - 581 .

12. Gao B.Y., Yue Q.Y., Wang Y. //Separ. and Purific. Technol. - 2007. - 56. - P.225 - 230.

13. Zhu B., Clifford D.A., Chellam S. //Water Res. -2005. - 39. - P.3098- 3108.

14. Yilmaz E., Boncukcuoglu R., Kocakerim M.//Hazard. Materials. -2007.-149. P. $475-481$.

15. Onder E., Savas A.K., Ogutveren U.//Separ. and Purific. Technol. - 2007. 52. - P. $527-532$.

16. Nabil S. Abuzaid, Alaadin A. Bukhari, Zakariya M. Hamouz // Adv. Environ. Res. - 2002. - 6. - P.325-333.

17. Zhua B., Clifford D.A., Chellam S.// Water Res. - 2005. -39. - P. 3098 - 3108.

18. Vepsalainen M., Ghiasvand M., Selin J., Pienimaa J., Repo E., Pulliainen M., Sillanpaa M. // Separ. and Purific. Technol. - 2009. - 69. - P. 255 - 260.

19. Chou W., Wang C., Hsu C., Huang K., Liu T. // Desalination. -2010. - 259. P.103 - 110 .

20. Leiknes T., Degaard H., Myklebust H.//Membrane Sci. - 2004. - 242. P. $47-55$.

21. Zazouli M.A., Nasseri S., Mahvi A.H., Gholami M., Mesdaghinia A.R., Younesian M. //Iran. J. Environ. Health Sci. and Eng. - 2008. - 5, N1. - P.11- 18.

22. Gao B.Y., Yue Q.Y., Wang B.J.// Chemosphere. -2002. -46, N6. - P. 809-813.

23. APHA /AWWA /WEF. Standard method for examination of water and wastewater, 20 th ed, Washington DC, American public health association publication, 2340. -1999 . 